\title{
Nanni Rojas-Albonico
}

Le droit au développement comme droit de l'homme

Verlag Peter Lang, Bern, 1984, 321 S., SF 58,-

Im Jahr 1977 bezeichnete die Menschenrechtskommission der Vereinten Nationen erstmals das Recht auf Entwicklung als Menschenrecht, im Jahr 1985 lagen der Generalversammlung der Vereinten Nationen bereits die Ergebnisse der Arbeit einer Gruppe von Regierungsexperten zu einer Deklaration über das Recht auf Entwicklung vor. Die Herausbildung dieses Menschenrechts der Gruppe der sogenannten Solidaritätsrechte hat eine breite und grundsätzliche Diskussion über seinen Inhalt, die Träger und seine rechtliche Qualifikation ausgelöst.

Als eine der ersten umfassenden Arbeiten im Sinne einer "Grundlagenforschung" zum Recht auf Entwicklung ist die im Lang-Verlag erschienene Dissertation von Nanni Rojas-Albonico ein umfassender und kompetenter Versuch einer ersten analytischen Durchdringung des neu postulierten Menschenrechts. Die Schrift beginnt mit einem Rückblick auf die Diskussion über Menschenrechte und Entwicklung, die vor allem die 70er Jahre beherrschte und wendet sich dann den Quellen, den Rechtssubjekten, dem Inhalt und den Pflichtsubjekten des Rechts auf Entwicklung zu.

Die Stärke des Buches liegt in der Aufarbeitung der einschlägigen Dokumente der Vereinten Nationen als Ergebnis der großen Zahl von Seminaren, Konferenzen und Resolutionen zum Themenkreis Menschenrechte und Entwicklung, wobei entsprechend dem Typus der Arbeit ein starkes theoretisches Anliegen sichtbar wird. Schwergewichtig findet sich die Behandlung des Begriffs und des Inhalts von Entwicklung selbst, insbesondere der Partizipation der Betroffenen als zentralem Element jeden Entwicklungsprozesses. Ein Defizit der Arbeit liegt jedoch in ihrer Beschränkung auf die nach klassischer Völkerrechtslehre allein relevanten Rechts- und Pflichtsubjekte des Völkerrechts des Menschenrechtsschutzes, nämlich Individuen und Staaten, auch wenn in den Schlußfolgerungen (S. 293) die Frage nach den Entwicklungsvölkern als einer funktionellen Rechtskategorie gestellt wird. Zum Recht auf Entwicklung als Recht der Völker findet sich nur ein kurzer Abschnitt betreffend die Kolonialvölker, während ansonsten als Anspruchsberechtigte nur die Einzelmenschen und die Entwicklungsländer untersucht werden. In keiner Weise wird auch auf die Afrikanische Charta der Menschenrechte und Rechte der Völker von 1981 eingegangen, wo das Recht auf Entwicklung als Recht der Völker erstmals Aufnahme in ein verbindliches Völkerrechtsinstrument gefunden hat. Somit enthält das Buch auch keine Aussage zum Verhältnis zwischen Menschenrechten und den Rechten der Völker, das z. B. die UNESCO seit Jahren sehr beschäftigt. Auf das Problem, daß Entwicklungsländer als Staaten schwerlich Anspruchsberechtigte von Menschenrechten sein können, wird nicht eingegangen. Umgekehrt wird bei den Pflichtsubjekten des Menschenrechts auf Entwicklung der Bedeutung der Staaten in ihrer kollektiven Dimension für die Verwirklichung des Rechts auf Entwicklung und damit der Rolle der bestehenden Institutionen der Staatengemeinschaft zu wenig Beachtung geschenkt. Die Autorin stellt selbst abschließend fest, daß "la reconnaissance d'un droit 
au développement comme droit de l'homme n'est guère concevable dans le cadre du droit international classique" (S. 291), zeigt jedoch mit Ausnahme des "Resolutionsrechts" der Vereinten Nationen wenig Ưberlegungen zu einer notwendigen Fortentwicklung traditioneller völkerrechtlicher Konzeptionen um den neuen Phänomenen des Menschenrechtsschutzes, wie dem Recht auf Entwicklung, besser Rechnung tragen zu können.

Wolfgang Benedek

Peter Macalister-Smith

International Humanitarian Assistance

Martinus Nijhoff publishers, 1985, 244 p., $\mathfrak{E} 33.00$

This book is a welcome contribution to the growing interest not only in the field of International Humanitarian Assistance but also to the slowly developing branch of Public International Law known as International Humanitarian Law.

The work, done in nine chapters begins with a colourful, but sincere foward by His Highness Prince Sadruddin Aga Khan, a former United Nations Commissioner for Refugees and therefore an undisputed expert in the subject of the book. At the end the author, in a form of annextures reproduces eight valuable documents very relevant to the content of the book. These range from the Geneva Convention of August 22, 1864 for the Amelioration of the conditions of the wounded in the armies in the field to the Draft Convention on the Expediting the delivery of Emergency Assistance of 1984 prepared under the auspices of the United Nations. The rich bibliography provided by the author makes the work a reliable source of materials for scholars with interest in International Humanitarian issues.

The book attempts to close the gap that exists in the legal instruments available today on International Humanitarian Assistance and their implementation. Its main focus is how the International community should deal with disasters when they occur and also how to prevent and mitigate disaster situations. The book also examines the interplay between International politics, the law and the concrete reality of the day.

Chapters one to three are mainly historical. Here the author examines the emergene of Humanitarian Assistance. He notes the influence of Christianity, some elements of medieval chivalry, medieval Indian law and Islamic Law in restraining resort to total violence in conflicts. The works of Natural Law theoreticians like E. de Vattel and J. J. Rousseau are noted to have had considerable impact on moderation in war and the advisability of humane behaviour especially to non-Combatants. The very first charitable organisations like the Order of the Knights of St. John of Jerusalem were established within the framework of Religion. Also recorded in this part of the book is the works of Henry Dunant on care for victims of armed conflicts which later led to the formation of the Red Cross movement; and also of Dr. Fridtjof Nansen in the field of Interantional 